\title{
IMPACT OF CLIMATE CHANGE ON IRRIGATED CROP WATER USE OF SELECTED MAJOR GROWN CROPS AND WATER DEMAND FOR IRRIGATION: A CASE OF ANGER SUB-BASIN, NILE BASIN OF ETHIOPIA
}

\author{
Geremew Fekadu Boru \\ Department of Agricultural Engineering, \\ Institute of Technology \\ Ambo University, Ambo, Oromia Regional \\ State, Ethiopia
}

Abstract - Understanding crop water use under changing climate condition is very important for developing irrigation projects to expand agricultural productivity. This study focus on climate change impact on irrigated crop water use of major grown crops and water demand for irrigation in Anger sub-basin, Ethiopia. Single GCM from Coupled Model Inter-comparison Project Phase 5 with single regional climate model and delta change bias correction approaches were used to project crop water requirement for the developed scenario over the study periods of 2020 s and 2080s and demand analysis for the current conditions. The result of the analysis shows that at the 2020s crop water requirement of the irrigated crops changes from the baseline period by $1.7 \%$ to $3.83 \%$ and $1.5 \%$ to $3.8 \%$ for RCP 4.5 and RCP 8.5 respectively. At $2080 \mathrm{~s}$ it changes from $3.36 \%$ to $7 \%$ and $3.58 \%$ to $12.7 \%$ for RCP 4.5 and RCP 8.5 respectively over the study area for all crops in the future respectively. Additionally, the demand analysis shows that at the current condition irrigation water demand was $2.096 \mathrm{Bm}^{3}$ which takes a lion's share with about $62 \%$ followed by environmental water demand about $35 \%$ and domestic and livestock shares the lowest water demand of $1.72 \%$ and $1.475 \%$ respectively over the sub-basin. This indicates crop water requirement is increasing due to climate change which is directly influencing the water demand of other sectors. Therefore, in the future period

\author{
Firaol Daba Regassa \\ Departement of hydraulics and water resource \\ Engineering, Institute of Technology \\ Ambo University, Ambo, Oromia Regional \\ state, Ethiopia
}

decrement of water resource due to climate change requires water management practices to

keep water demand in place to continue agricultural practices and future development plans of agriculture in the sub-basin.

Keywords: Anger sub-basin, CWR, Water demand, Climate change, GCM, RCM

\section{INTRODUCTION}

Ethiopia is one of the most vulnerable countries to climate variability. The agriculture is the main source of livelihood for about $85 \%$ of Ethiopia's population and contributes more than $45 \%$ of GDP, $80 \%$ to labor force and $85 \%$ to foreign exchange earnings is highly susceptible to climate change [1]. The warming trend and climate variability imposes its impact on crop production with raising temperature and evaporative demand. Subsistent and small holder farmers who have less capacity to adaptation of climate change produce more than $95 \%$ of crop production which is rainfall dependent [1] are influenced by climate change.

In addition to rainfed agriculture, climate change influence the irrigated crops since irrigated crops are vulnerable to climate change and climate change affect the soil moisture during growing season and the soil temperature and water content in crop root zone during non-growing season [2] and also affect crop yield, water demand, effective water supply and availability for irrigation [3]. 
Ethiopia has considerable potential for agricultural development involving the substantial variation in crops grown across the countries at different regions and agro ecologies. About $96 \%$ of the total area cultivated account by smallholder farmers and generate the key share of the total production for the main crops [4]. Similarly, Anger sub-basin is one of the Blue Nile river basin which is characterized nearly by all agro-ecological climatic distribution (tepid sub-humid mid highlands, warm moist highlands and Warm sub-humid lowlands) and the production of cash and cereal crops like (maize, potatoes, tomatoes, sesame, cotton, pepper, wheat etc) practiced on rainfed based mostly and some of them by irrigation system. However, both production systems are vulnerable to climate change which may affect the crop growth and yield.

Additionally, now a day in the sub-basin different irrigation projects are practiced, planned and start construction based on water avaialability in the sub basin ranging from small scale to large scale schemes to increase the income and food sufficiency of the peoples. In some of irrigation schemes in the subbasin, climate change has significant impact on the crop yield [5]. But the analysis in relation to climate change on irrigated crop water use does not carried out yet. Therefore, it's essential to assess the climate change influence on crop water use and water demand for irrigation. Hence the study is designed to assess the current and future crop water use of major crop grown under climate changing scenarios and estimate water available for irrigation by analyzing water demand of other sectors.

\section{MATERIAL AND METHODS}

\subsection{Description of the study area}

The research was conducted in Anger sub-basin of the Upper Blue Nile River Basin, which is located in Oromia region in Western, Ethiopia. Geographically, it is located in between latitudes $9^{0} 08^{\prime}$ and $10^{\circ}$ $05^{\prime}$ North latitude and $36^{\circ} 01^{\prime}$ and $37^{\circ} 07^{\prime}$ (Figure 1). The altitude varies approximately from 868 masl to 3144 masl in the sub-basin. The sub-basin is characterized by unimodal rainfall pattern from June to September (long and heavy summer rain), from October to January (Birra) season, when rainfall comes to end and medium to short dry season is characterized and from February to May (Bona) season of short rainy seasons is available (http://www.meteo-ethiopia.net/climate. htm October 2014).

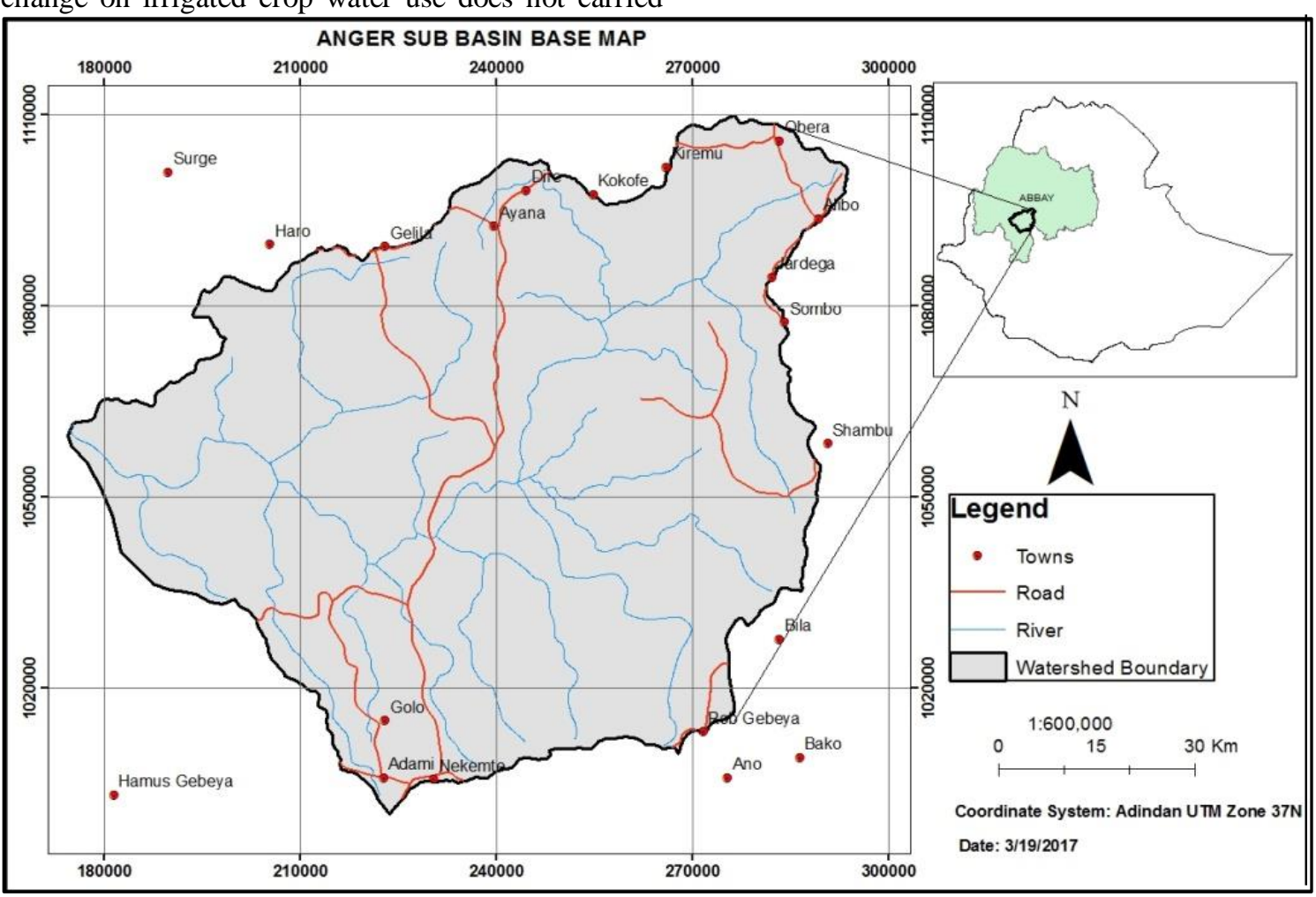

Figure 1. Location of the study area 


\section{International Journal of Engineering Applied Sciences and Technology, 2020 \\ Vol. 4, Issue 9, ISSN No. 2455-2143, Pages 452-464 \\ Published Online January 2020 in IJEAST (http://www.ijeast.com)}

The mean annual rainfall ranges from $1246 \mathrm{~mm}$ at eastern lowlands to $2067 \mathrm{~mm}$ in highland areas of the sub-basin. The average annual daily maximum and minimum temperatures in the three main agro-

\subsection{Data used and data analysis}

Historical climate data required for the analysis are collected for about 29 year (1986-2014) from ecological zones (tepid sub-humid mid highlands, warm moist highlands and Warm sub-humid lowlands) vary from $22.6{ }^{\circ} \mathrm{C}$ to $31.2{ }^{\circ} \mathrm{C}$ and $11.57{ }^{\circ} \mathrm{C}$ to $15.52{ }^{\circ} \mathrm{C}$ respectively over the sub-basin.

meteorological Agency for the stations available within the study area based on Agro-ecological zones.

Table 1: Location of meteorological station selected for analysis

\begin{tabular}{|l|l|l|l|}
\hline No & Station name & Latitude & Longitude \\
\hline 1 & Anger & 207009.2209 & 1025436.545 \\
\hline 2 & Nekemte & 221158.1145 & 1005036.575 \\
\hline 3 & Didessa & 181462.3886 & 1038544.347 \\
\hline 4 & Gida Ayana & 238623.8369 & 1091606.355 \\
\hline
\end{tabular}

The data quality assessment for this study was carried out by RclimDex.1 software (http://cccma.seos.uvic.ca/ETCCDMI) for data quality control, XLSTAT software (www.xlstat.com) for outlier detection, RHtest R analytical tool [6] for homogeneity test and first order Markov chain simulation model of INSTAT used for filling the rainfall missed data [7] and interpolation techniques for temperatures data filling.

\subsection{Future data Set}

Future climate data set were obtained from the high resolution of $0.44^{\circ} \times 0.44^{\circ}(\sim 50 \mathrm{~km} \times 50 \mathrm{~km})$ regional climate models, Coordinated Regional Climate Downscaling Experiment (CORDEX-Africa database website; [8]. Accordingly, EC_EARTH driving model was used and the downscaling was accomplished by the latest version of Rossbey Center using their regional climate model_RCA4. In this study, RCP 4.5 and RCP 8.5 emission scenarios output data from (2015-2100) of the earth`s system model were considered. Due to the output of the regional climate models cannot use directly for impact assessment bias correction is therefore applied to compensate for any tendency to overestimate or underestimate the mean of downscaled control and future simulated variables prior to use for crop water use impact studies. For this study, Delta change method was used for post processing and bias correction of RCMs used by [9] and also developed in CMhyd software for simplification to extract and bias correct the dynamically downscaled climate data for further impact analysis according to the procedures in figure (2).

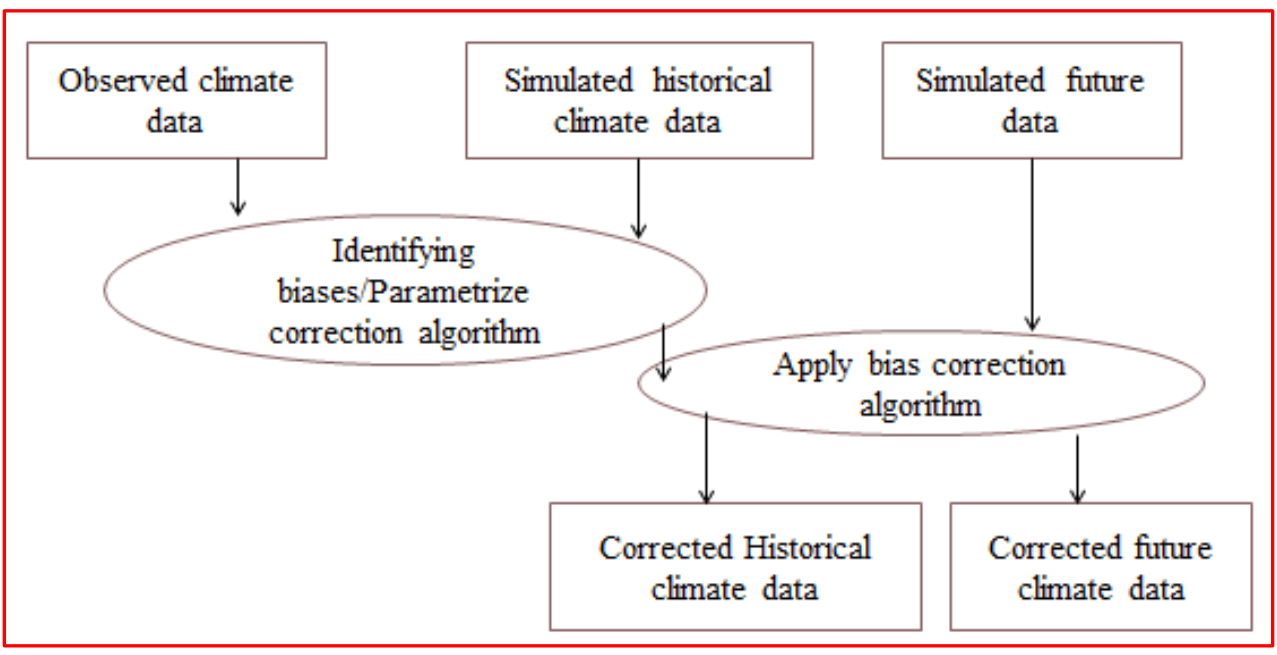

Figure 2: Bias correction Framework: Source [10] 


\section{International Journal of Engineering Applied Sciences and Technology, 2020 \\ Vol. 4, Issue 9, ISSN No. 2455-2143, Pages 452-464 \\ Published Online January 2020 in IJEAST (http://www.ijeast.com)}

\subsection{Crop water use estimation}

The most common procedure for estimating crop water use or crop evapotranspiration $(\mathrm{ETc})$ is the crop coefficient $(\mathrm{Kc})$ approach. The FAO PenmanMonteith equation (P-M) is widely recommended method to estimate ETo because of its detailed climatological data required and its accommodation to small time periods. Due to not all data used for crop evapotranspiration for the major grown crops in the study area [12] was employed

$\mathrm{ET}_{\mathrm{o}}=0.0023\left(\mathrm{~T}_{\max }-\mathrm{T}_{\min }\right){ }^{0.5} *\left(\mathrm{~T}_{\mathrm{ave}}-17.8\right) \mathrm{R}_{\mathrm{a}}$

Where; $\mathrm{ETo}=$ reference evapotranspiration estimated by Hargreaves $(\mathrm{mm} / \mathrm{d})$

Tmax $=$ maximum daily temperature $\left({ }^{0} \mathrm{C}\right)$

$\mathrm{Tmin}=$ minimum daily temperature $(0 \mathrm{C})$

Tave $=$ average daily temperature $(0 \mathrm{C})$

$\mathrm{Ra}=$ extraterrestrial radiation $(\mathrm{MJ} / \mathrm{m} 2 / \mathrm{d})$

Crop evapotranspiration or crop water use can be assessed by multiplying/product of the two factors
penman-Monteith are available, the reduced weather data equation are appropriate for the study area. In this research a simplified Hargreaves and Samani [11] equation used, which requires only temperature, day of year and latitude for calculating current and future potential evapotranspiration to estimate the

the reference evapotranspiration (ETo) and the crop coefficient, based on the following relationship:

$$
\mathrm{ETc}=\mathrm{Kc}^{*} \mathrm{ET}_{\mathrm{O}}
$$

Where, Kc is crop coefficient,

The crop water use of major grown crops was then derived through a crop coefficient that integrated the combined effects of crop transpiration and soil evaporation into a single crop coefficient $(\mathrm{Kc})$, based on the following relationship[13].

Table 2: Growth stages and crop coefficients of selected major irrigated crops in the sub-basin

\begin{tabular}{|l|l|l|l|l|l|l|l|l|l|}
\hline No & Crop & \multicolumn{5}{|c|}{ Growth stages } & \multicolumn{2}{l|}{ Crop Coefficient } \\
\hline & & Initial & Dev't & Mid & Late & Kcin & Kc Dev't & Kc mid & Kc late \\
\cline { 3 - 11 } 1 & Maize & 30 & 40 & 50 & 30 & 0.3 & 0.7 & 1.2 & 0.8 \\
\hline 2 & Potato & 25 & 30 & 40 & 20 & 0.5 & 0.75 & 1.1 & 0.9 \\
\hline 3 & Cabbage & 20 & 25 & 60 & 15 & 0.48 & 0.8 & 1.1 & 0.9 \\
\hline 4 & Tomato & 30 & 40 & 42 & 25 & 0.5 & 0.7 & 1.15 & 0.8 \\
\hline 5 & Sugarcane & 45 & 75 & 245 & 115 & 0.4 & 1.25 & 1.25 & 0.75 \\
\hline
\end{tabular}

\subsection{Impact assessment analysis}

Crop water use for the selected irrigated crops grown in the study area was estimated from observed data and bias corrected future climate data. The impact of climate change on the irrigation water requirement for these selected crops was determined for monthly time step. For both RCP 4.5 and RCP 8.5 scenarios, the calculated irrigation water use is averaged in to monthly in two time horizons (2021-2040 and 20812100). Finally, the projected average of irrigation water use is subtracted from the corresponding average monthly irrigation water use of the base line time period which is calculated from [11] equation.

\subsection{Water Demand Estimation}

Estimation of water distribution for domestic, livestock and environmental water requirement is necessary to know the volume of water to be abstracted for irrigation. Domestic water demand was estimated based on sub-basin population [15] and the minimum standard required per person per day.
Accordingly, The World Health Organization (WHO) recommends about 100 liter of water per person per day to ensure that most basic needs are met and few health concerns arise [16]. For this study per capita water supply $100 \mathrm{l} / \mathrm{c} /$ day $\left(36.5 \mathrm{~m}^{3} / \mathrm{c} /\right.$ year $)$ is used.

Livestock water demand was estimated based on subbasin livestock population [17] and their daily consumption rate (Table 4.1). For domestic and livestock water demand was estimated by multiplying the number of users by standard consumption. It is given according to the following equation [18].

$$
C R=\frac{N^{*} q^{*} t}{1000}
$$

Where,

$\mathrm{CR}$ is livestock and Human consumptive requirement $\left(\mathrm{m}^{3}\right)$;

$\mathrm{N}$ is the user size (number);

$\mathrm{q}$ is the consumptive rate (1t/day)

$t$ is the number of days 
Environmental water requirement is Key in order to protect natural reserves and preserve the ecosystems. It has been estimated that approximately (20-50) percent of the mean annual river flow in different basins needs to be allocated to freshwater-dependent ecosystems to maintain a fair condition [19]. For this study $35 \%$ of mean annual river flow was considered.

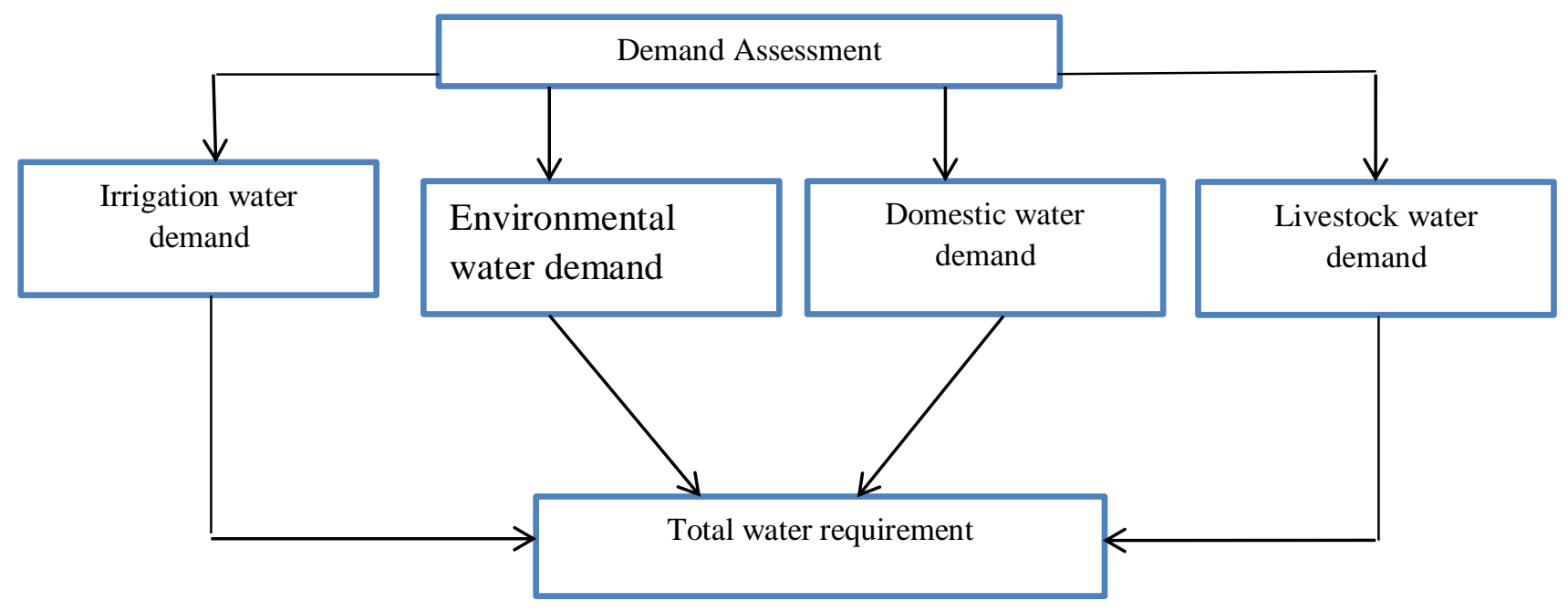

Figure 3: Flow chart for demand assessment in Anger sub-basin

The irrigation water demand was calculated based on irrigated crops in the sub-basin. Climatic data used for calculating irrigation water requirement of the major grown crops was selected depending up on the Agro-ecological zones and the mean areal of climatic Nekemte, Gumbi, Biyo, Leku Uke, Uke, Dale, Chigsa and Dembi Gusu projects as well as small irrigation projects are situated in Anger sub-basin are categorized under Anger agricultural water demand estimation. The total land area of 54435 ha covered by small to large irrigation projects of the study area was proposed to be irrigated by different crops during dry season (full irrigation). Also, some supplementary irrigation water requirement was considered in the study area. However, for determination irrigation water requirement of all crops over the whole Anger sub-basin, water requirement $\mathrm{m}^{3}$ per hectare for each crop was taken from the feasibility study of Anger irrigation project [22]. data was used. According to study of [20] and [21] the existing and planned schemes for irrigation including large to medium irrigation projects like, Anger,

\section{RESULT AND DISCUSSION}

3.1. Regional Climate Model Improvements with Bias Correction

The outputs of the raw regional climate models underestimate and overestimate the mean monthly rainfall and temperatures as compared to areal mean monthly rainfall and temperatures (Figure 4 on left panel). These outputs are adequately corrected by delta change method for precipitation and temperature (Figure 4 on the right panel) and the results shows good agreement. This implies that the bias corrected output of the model well captures the representativeness the study area. 


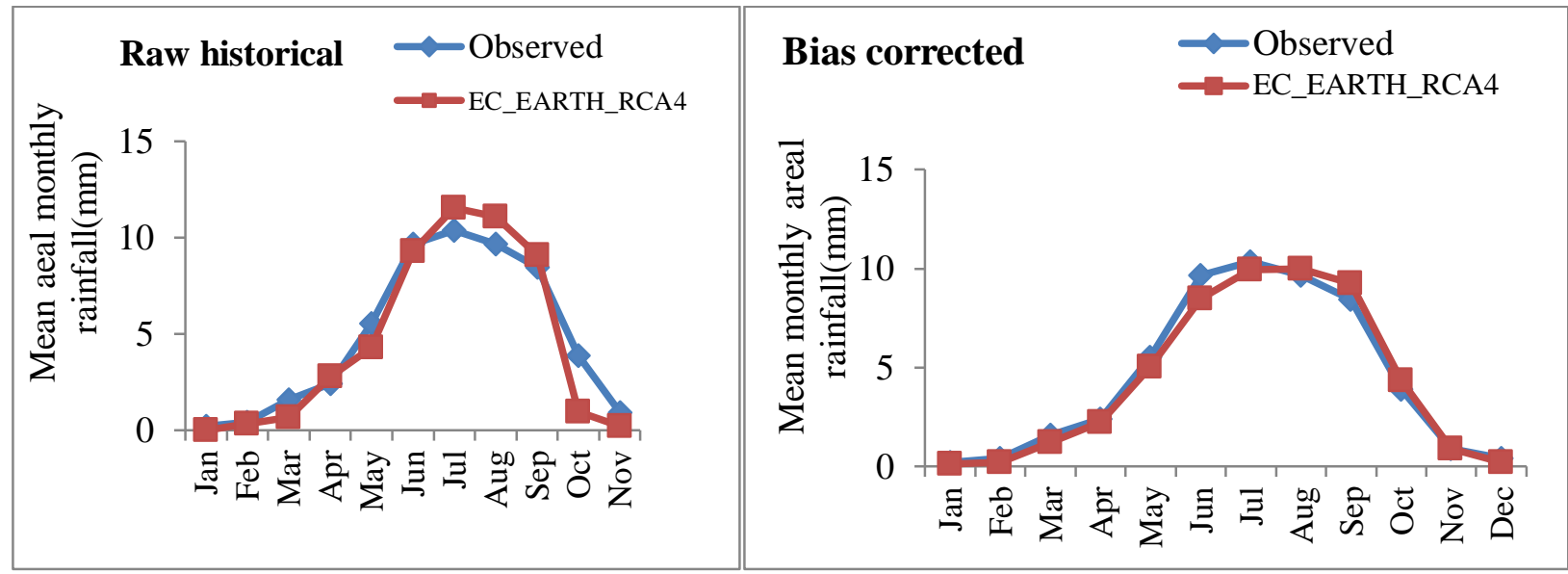

Figure 4a: Comparison of simulated and observed mean monthly rainfall before (on the left panel) and after (on the right panel) of bias correction

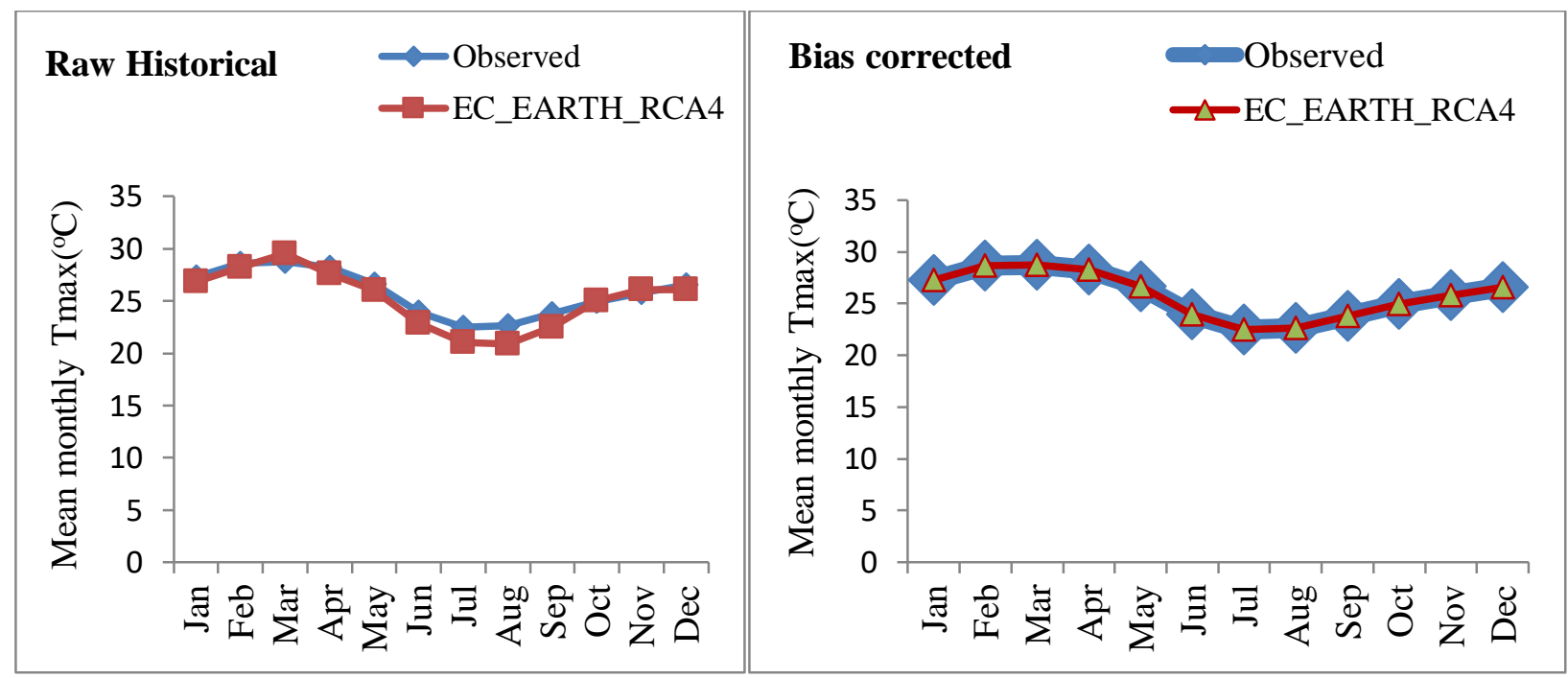

Figure 4b: Comparison of simulated and observed mean monthly Tmax rainfall before (on left panel) and after (on right panel) of bias correction

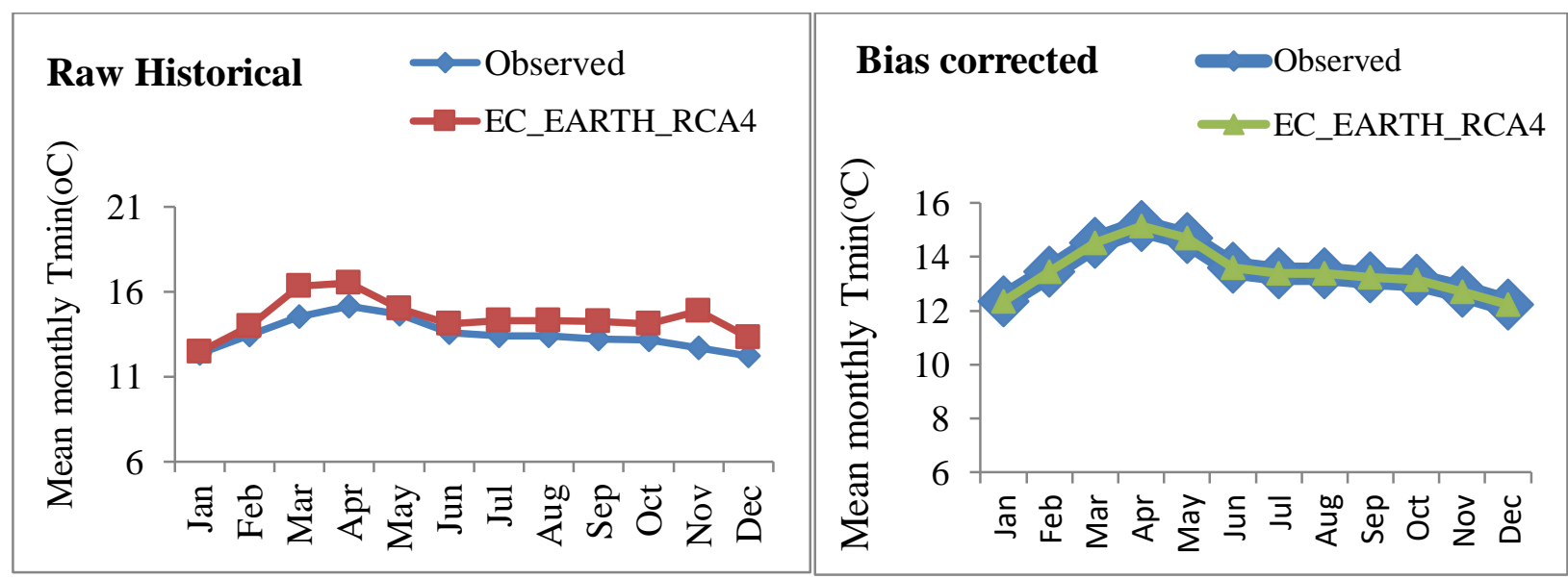

Figure 4c: Comparison of simulated and Observed mean monthly Tmin before (on left panel) and after (on the right panel) of bias correction 
3.2. Estimation of future reference crop evapotranspiration (ETo)

Reference evapotranspiration (ETo) was estimated for base period and future climate scenarios periods $(2020,2080$ s) by bias corrected future climate data (Figure $5 \& 6$ ). The result shows that at the baseline period ETo varies in the range of 141.5 to 190.46 $\mathrm{mm} / \mathrm{month}$ in the warm sub-humid agro ecological zones. The ETo increases gradually from approximately $164.6 \mathrm{~mm} / \mathrm{month}$ in January to the peak value of about $190.46 \mathrm{~mm} /$ day in March due to hot temperature and low rainfall in this month. Then it decreases gradually to $141.5 \mathrm{~mm} / \mathrm{month}$ in August. The minimum and maximum ETo was predicted to be in the range of $141.45-196.3 \mathrm{~mm} / \mathrm{month}$ at $2020 \mathrm{~s}$ and $153.14-197.9 \mathrm{~mm} / \mathrm{month}$ at $2080 \mathrm{~s}$ over the lowland areas under RCP 4.5 scenario (Figure 5) while in highland areas of the sub-basin the minimum and maximum ETo was observed in July and March respectively having $(106.4 \mathrm{~mm} / \mathrm{month})$ and $(149.3$ $\mathrm{mm} / \mathrm{month}$ ) magnitudes at 2080s (Figure 6). Change in ETo at 2080s was high as compared with 2020s due to increasing temperature and significant decreasing of rainfall over the study area in both RCP's.

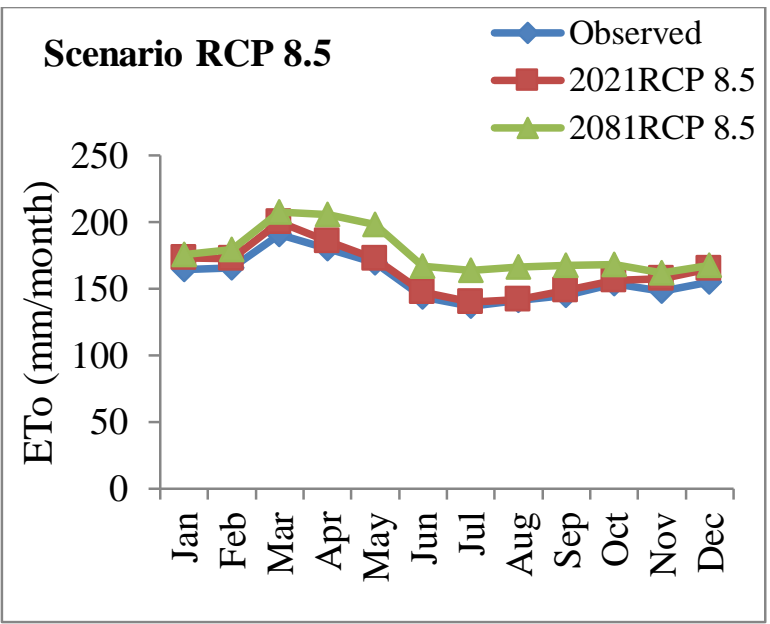

Figure 5: Evapotranspiration (ETo $)$ at base period, 2020s, 2080s scenarios periods in warm sub-humid (lowland) AEZ of the study area

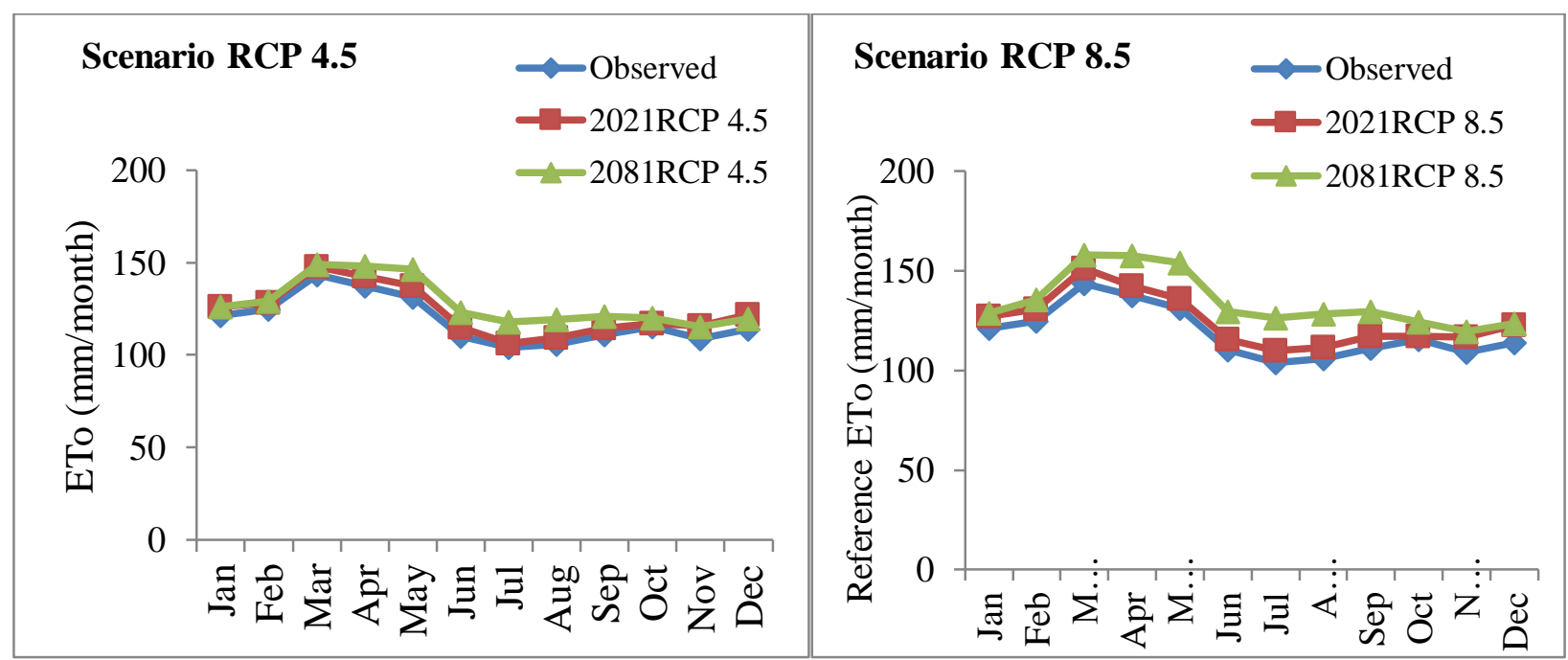

Figure 6: Evapotranspiration (ET ${ }_{\mathrm{O}}$ ) at base period, 2020s, 2080s scenario periods in warm sub-humid (high land) AEZ of the study area 


\section{International Journal of Engineering Applied Sciences and Technology, 2020 \\ Vol. 4, Issue 9, ISSN No. 2455-2143, Pages 452-464 \\ Published Online January 2020 in IJEAST (http://www.ijeast.com)}

The analysis reveals that annual potential evapotranspiration are predicted to increase with increase in temperature. The average projected annual reference crop evapotranspiration increase with $2.8 \%, 7.3 \%$ at 2020 s and $3.8 \%, 7.7 \%$ at 2080 s in lowland and highlands parts respectively for RCP 4.5 scenario. Similarly, the projected annual ETo increase by $3.5 \%, 12.6 \%$ and $4.9 \%, 13.2 \%$ at 2020 s and 2080s in lowland and highland parts of Anger sub-basin under RCP 8.5 scenario (Table 3). The seasonal ETo increases over the sub-basin and the highest increase were observed in kiremt seasons in future. This result is supported by $[23,24,25]$ that at the end of the $21 \mathrm{st}$ century potential evapotranspiration was increase in all months of the year.

Table 3: Percentage change in Reference ETo (\%) at seasonal and annual basis over Anger sub-basin

\begin{tabular}{lcccc|cccc}
\hline \multicolumn{4}{c}{ RCP 4.5 Scenario } & \multicolumn{3}{c}{ RCP 8.5 scenario } \\
\hline Seasons & \multicolumn{2}{c}{ Lowland } & \multicolumn{2}{c|}{ Highland } & \multicolumn{2}{c}{ Lowland } & Highland \\
\hline & $2020 \mathrm{~s}(\%)$ & $2080 \mathrm{~s}(\%)$ & $2020 \mathrm{~s}(\%)$ & $\begin{array}{c}2080 \mathrm{~s} \\
(\%)\end{array}$ & $2020 \mathrm{~s}(\%)$ & $2080 \mathrm{~s}(\%)$ & $2020 \mathrm{~s}(\%)$ & $\begin{array}{c}\text { 2080s } \\
(\%)\end{array}$ \\
\hline ONDJ & 4.2 & 4.9 & 4.6 & 4.7 & 4.8 & 8.4 & 5.3 & 8.0 \\
JJAS & 1.3 & 10.2 & 3.2 & 11.6 & 2.0 & 17.2 & 5.2 & 19.0 \\
FMAM & 3.1 & 6.7 & 3.6 & 6.7 & 3.5 & 12.1 & 4.2 & 12.6 \\
Annual & 2.8 & 7.3 & 3.8 & 7.7 & 3.5 & 12.6 & 4.9 & 13.2 \\
\hline
\end{tabular}

3.3. Future water requirement of selected major grown crops

Crop water use estimation was carried out for different climate change scenarios and scenario period. The result reveals that crop water requirement increases in the future for all major crops grown (Maize, Tomato, potato, Cabbage and sugarcane) as compared to baseline period due to increasing temperature as well as evapotranspiration over the study area (Table 4). In the period 2020s and 2080s, maize shows increment in crop evapotranspiration by $2.38 \%, 3.22 \%$ and $3.36 \%, 7.81 \%$ for RCP 4.5 and
RCP 8.5 scenarios respectively. Similarly, crop evapotranspiration of Tomato may increase by $3.83 \%, 3.26 \%$ and $3.45 \%, 3.58 \%$ at 2020 s and 2080 s respectively for RCP 4.5 and $\mathrm{RCP} 8.5$ scenarios. Increase CWR also $2.78 \%, 3.74 \%$ and $3.35 \%, 7.59 \%$ at 2020s and 2080s respectively for RCP 4.5 and RCP 8.5 scenarios for cabbage crop. Potato water requirement increased by $3.3 \%$ and $4.0 \%$ and $3.8 \%$ and $7.9 \%$ at 2020 s and 2080 s respectively for RCP 4.5 and RCP 8.5 scenarios. In similar way, sugarcane water requirement increase ranges from $1.7 \%$ to $7.1 \%$ and $1.5 \%$ to $12.7 \%$ for both scenarios RCP 4.5 and RCP 8.5 scenarios during both time slices over the Anger sub-basin.

Table 4: Total water requirement during growth stages and Percentage changes under climate change condition of the selected crops in Anger sub-basin.

\begin{tabular}{|c|c|c|c|c|c|c|c|c|c|}
\hline \multirow{3}{*}{ Crop } & \multirow[b]{3}{*}{ Baseline } & \multicolumn{4}{|c|}{ Total CWR (mm/growth period) } & \multicolumn{4}{|c|}{ Percentage change $(\%)$ per growth period } \\
\hline & & \multicolumn{2}{|c|}{2020 's } & \multicolumn{2}{|c|}{2080 's } & \multicolumn{2}{|c|}{2020 's } & \multicolumn{2}{|c|}{2080 's } \\
\hline & & RCP 4.5 & RCP 8.5 & $\mathrm{RCP} 4.5$ & RCP 8.5 & RCP 4.5 & RCP 8.5 & RCP 4.5 & RCP 8.5 \\
\hline Maize & 653.4 & 668.9 & 674.5 & 675.4 & 704.4 & 2.38 & 3.22 & 3.36 & 7.81 \\
\hline Tomato & 610.1 & 633.4 & 629.9 & 631.1 & 631.9 & 3.83 & 3.26 & 3.45 & 3.58 \\
\hline Cabbage & 503.3 & 517.3 & 522.1 & 520.1 & 541.5 & 2.78 & 3.74 & 3.35 & 7.59 \\
\hline Potato & 472.271 & 487.6 & 490.2 & 491.3 & 509.6 & 3.3 & 3.8 & 4.0 & 7.9 \\
\hline Sugarcane & 2620.57 & 2665.3 & 2660.9 & 2804.3 & 2958.0 & 1.7 & 1.5 & 7.0 & 12.9 \\
\hline
\end{tabular}


Figure (7) below shows crop water use of the representative crops at different growth stages and it indicates that for all crops, crop water requirement is increasing from the initial stage to the maximum at mid- stage and decrease at the late season both under current(Figure 7a) and future time periods(Figure 7b).

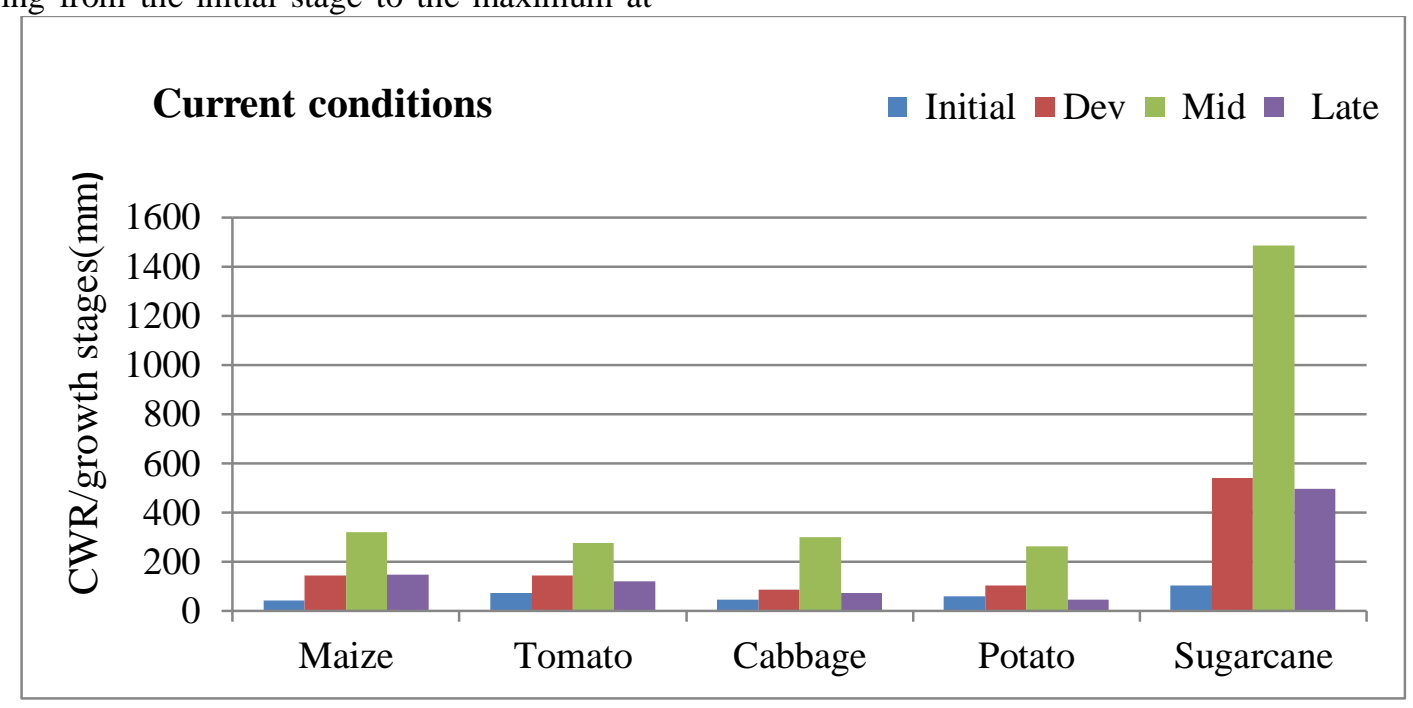

Figure 7a: Crop water requirement of major grown crops at baseline period in Anger sub-basin
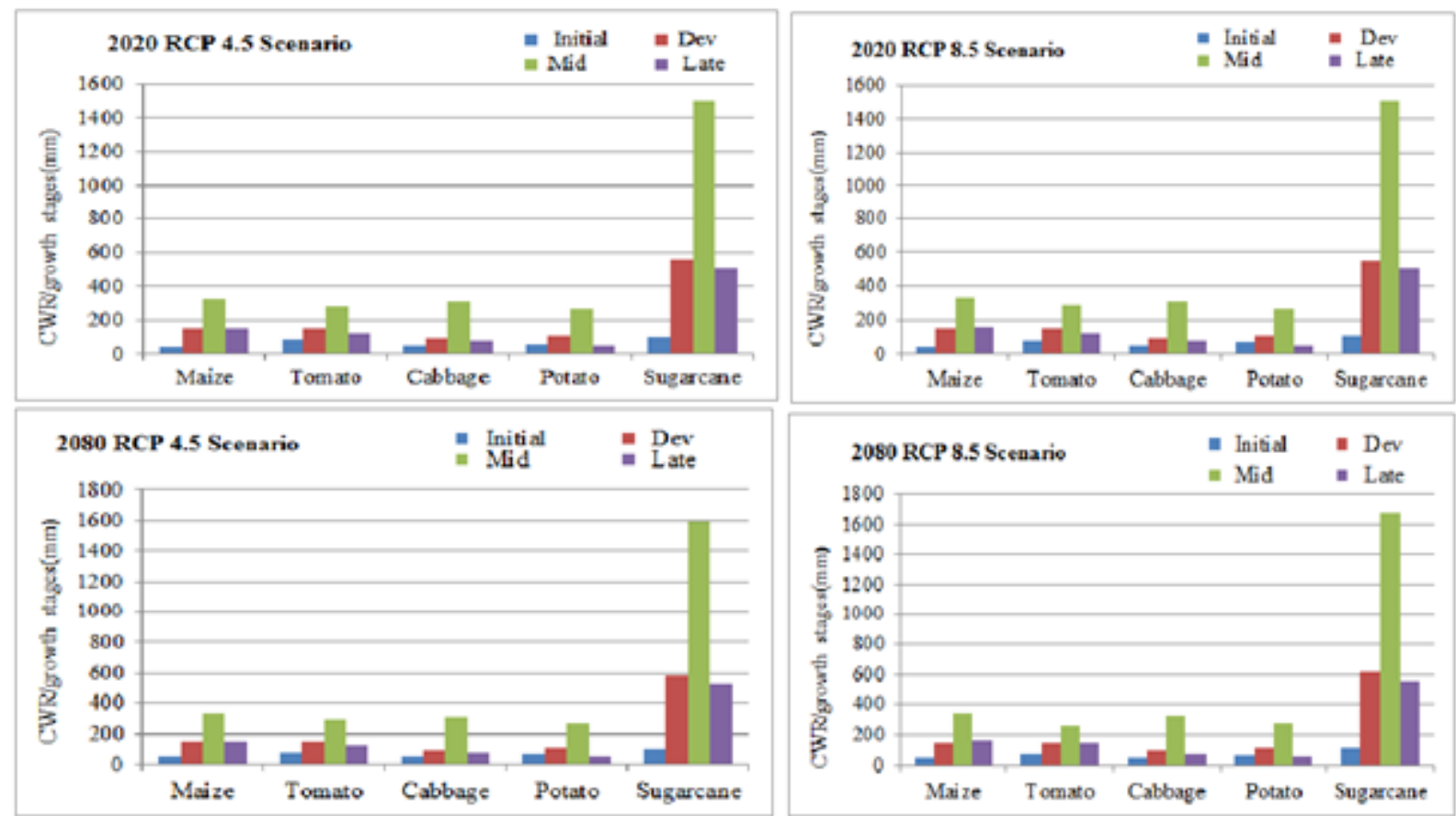

Figure 7b: Crop water requirements of major irrigated crops over Anger sub-basin at 2020s, 2080s during full irrigation (dry seasons) under RCP 4.5 and RCP 8.5 Scenarios

\subsection{Irrigation water demand analysis}

The total annual surface water availability over Anger sub-basin was estimated in my first paper and it was $3.396 \mathrm{BCM} /$ year at base period [26].
Accordingly, the total domestic water requirement of the sub-basin will be $0.059274 \mathrm{BCM} /$ year. 0.051 $\mathrm{BCM} /$ year were consumed by livestock over the subbasin (Table 5) 


\section{International Journal of Engineering Applied Sciences and Technology, 2020 \\ Vol. 4, Issue 9, ISSN No. 2455-2143, Pages 452-464 \\ Published Online January 2020 in IJEAST (http://www.ijeast.com)}

Table 5: Livestock population in the Basin and their Water Requirement

\begin{tabular}{cccc}
\hline $\begin{array}{c}\text { Type of animal in the } \\
\text { sub-basin }\end{array}$ & $\begin{array}{c}\text { Livestock } \\
\text { population(million) }\end{array}$ & $\begin{array}{c}\text { Average water requirement } \\
\text { (L/day/head) }\end{array}$ & Water requirement (BCM/year) \\
\hline Cattle & 2.186415 & 54 & 0.0446 \\
Sheep/goat & 0.765113 & 7.14 & 0.0021 \\
Equine & 0.231435 & 45.6 & 0.0034 \\
Poultry & 1.121751 & $450 \mathrm{~L} / 1000 \mathrm{birds} /$ day & 0.00019 \\
Total & & & $\mathbf{0 . 0 5 1}$ \\
\hline
\end{tabular}

\section{Source: [19]}

The environmental water requirement was estimated to be about $1.19 \mathrm{BCM} / \mathrm{year}$ based on the recommended range considered. Then, the rest water volume available within the sub-basin is used for irrigation. So, about $2.096 \mathrm{BCM} /$ year of water is available for irrigation purpose in Anger sub-basin. This analysis reveals that the irrigation water demand takes a lion's share with about $62 \%$ followed by water needed by environmental protection water demand about $35 \%$ and the domestic and livestock shares the lowest water demand of $1.72 \%$ and $1.475 \%$ respectively over the sub-basin.
Agricultural water demand over Anger sub-basin determined based on the annual water requirement for each crop per hectare as estimated by [22]. The area covered by each crop for identified irrigable area was calculated in addition to data achieved for small scale schemes from East Wollega Irrigation Development authority report $[5,21]$. The productive of the two factors gives the water requirement by crop annually and accordingly the total agricultural water requirement during dry season (full irrigation) was about $114.64 \mathrm{Mm}^{3}$ (Table 6).

Table 6: Crop water requirement $\left(\mathrm{Mm}^{3}\right)$ per hectare for proposed and functional projects in the sub-basin during dry seasons [22]

Dry season proposed and irrigated crops over Anger sub-basin

\begin{tabular}{lccc}
\hline \multicolumn{1}{c}{ Crops } & Area (ha) & $\mathrm{m}^{3} / \mathrm{ha}$ & $\mathrm{Mm}^{3}$ \\
\hline Tomatoes - fresh & 226.94 & 9485 & 2.15 \\
Peppers - fresh & 53.85 & 9578 & 0.52 \\
Onions & 242.33 & 9009 & 2.18 \\
Cabbage & 380.80 & 5153 & 1.96 \\
Sweet potatoes & 69.24 & 8446 & 0.58 \\
Carrots & 53.85 & 8169 & 0.44 \\
Eggplants & 53.85 & 7963 & 0.43 \\
Potatoes & 226.94 & 8509 & 1.93 \\
Leaf vegetables & 242.33 & 5157 & 1.25 \\
Melons \& Watermelons & 53.85 & 7125 & 0.38 \\
Cucurbits & 34.62 & 6085 & 0.21 \\
Beans & 138.47 & 5709 & 0.79 \\
Maize - fresh ears & 692.36 & 7583 & 5.25 \\
Maize - grains & 3461.81 & 8242 & 28.53
\end{tabular}




\begin{tabular}{lccc} 
Sorghum & 865.45 & 7518 & 6.51 \\
Soybeans & 2423.27 & 7788 & 18.87 \\
Castor beans & 865.45 & 7680 & 6.65 \\
Peppers - spice & 173.09 & 8295 & 1.44 \\
Fodder Legumes & 865.45 & 5385 & 4.66 \\
Cotton & 1730.90 & 7455 & 12.90 \\
Paprika & 1384.72 & 6822 & 9.45 \\
Tomatoes - industry & & 8731 & \\
Total & 865.45 & & 114.64 \\
\hline
\end{tabular}

The water requirement volume needed by crops as supplementary is to be about $384.43 \mathrm{Mm}^{3}$ (Table 7).
Therefore, the irrigation water demand of the crops grown over potential irrigable area at present time was estimated about $529.07 \mathrm{Mm}^{3}$.

Table 7: Crop water requirement $\left(\mathrm{Mm}^{3}\right)$ corresponding to area covered requires supplementary irrigation [22].

Supplementary irrigation

\begin{tabular}{lccc}
\hline Crops & Area(ha) & $\mathrm{m}^{3} / \mathrm{ha}$ & $\mathrm{Mm}^{3}$ \\
\hline Tomatoes - fresh & 85.57 & 857 & 0.07 \\
Peppers - fresh & 23.77 & 857 & 0.02 \\
Onions & 85.57 & 857 & 0.07 \\
Sweet potatoes & 23.77 & 857 & 0.02 \\
Carrots & 23.77 & 857 & 0.02 \\
Eggplants & 23.77 & 857 & 0.02 \\
Potatoes & 109.35 & 857 & 0.09 \\
Leaf Vegetables & 42.79 & 857 & 0.04 \\
Beans & 23.77 & 857 & 0.02 \\
Maize - fresh ears & 1283.62 & 857 & 1.1 \\
Maize - grains & 7487.77 & 857 & 6.42 \\
Sorghum & 2995.11 & 857 & 2.57 \\
Groundnuts & 3209.04 & 857 & 2.75 \\
Noug & 109.35 & 857 & 0.09 \\
Sesame & 427.87 & 857 & 0.37 \\
Flax & 109.35 & 857 & 0.09 \\
Sugar Cane -small holders & 1069.68 & 9128 & 9.76 \\
Legumes (green manure) & 2139.36 & 857 & 1.83 \\
Various crops & 66.56 & 857 & 0.06 \\
Sugarcane & 39329.98 & 9128 & 359 \\
Total & & & 384.43 \\
\hline
\end{tabular}

The water abstracted for irrigation purpose from the analysis $2.096 \mathrm{Bm}^{3}$ and the crop water requirement estimated is $529.07 \mathrm{Mm}^{3}$.
This indicates that there is water available over the sub-basin at baseline period for expansion of 


\section{International Journal of Engineering Applied Sciences and Technology, 2020 \\ Vol. 4, Issue 9, ISSN No. 2455-2143, Pages 452-464 \\ Published Online January 2020 in IJEAST (http://www.ijeast.com)}

irrigation projects to increase agricultural productivity and economic growth of the country.

\section{CONCLUSION}

Estimating amount of water requirements for crop under climate change in particular area is necessary for agricultural production and its management. Due to the increase of temperature the rate of evapotranspiration would increase which directly increase the rate of crop water use. Thus, the result shows that crop water use of the major grown crops were higher at the mid stage than others both at baseline and scenario periods. The crop water use of tomato and potato increase in higher by $3.83 \%$ and $3.8 \%$ respectively in 2020 s for both RCPs than other crops and the increment of sugarcane water use were $7 \%$ and $12.9 \%$ in 2080 s for both RCP 4.5 and RCP 8.5 respectively. This increasing crop water requirement results crops water stress in scenario periods. In response to such condition some water management and adaptation were required to reduce water consumption by crops based on crop varieties that has short growth period, water stress tolerant crops and providing new varieties especially of cabbage, potato, tomato, maize and sugarcane which could resist high evapotranspiration under changing climatic condition.

Irrigation water demand was estimated based on current conditions and the analysis reveals that the irrigation water demand takes a lion's share with about $62 \%\left(2.096 \mathrm{Bm}^{3}\right)$ followed by environmental water demand about $1.19 \mathrm{Bm}^{3}(35 \%)$ and the domestic and livestock shares the lowest water demand of $1.72 \% \quad\left(0.059274 \mathrm{Bm}^{3}\right) \quad$ and $1.475 \%\left(0.051 \mathrm{Bm}^{3}\right)$ respectively over the sub-basin.

The results of this study should be taken with care and be considered as representative of the likely future rather than accurate predictions of crop water use of crops. The analysis is based on single GCM driving model and regional climate model for future crop water use projections. Therefore, to increase the accuracy of the prediction, the studies on climate change impacts should include different GCM driving model with different RCM output is necessary but the obtained result helps the policy makers and planners of water resources for future and suggest that water saving techniques are required to satisfy increasing crop water use under scenario periods.

\section{REFERENCE}

[1] MoFED (Ministry of Finance and Economic Development, "Survey of the Ethiopian economy", Addis Ababa, Ethiopia, 2006.

[2] Tan CS, Reynolds WD, "Impacts of recent climate trends on agriculture in southwestern Ontario. Canadian", Water Resources Journal, 28(1), 87-97, 2003.

[3] Schlenker W, Hanemann, WM, Fisher AC, "Will US agriculture really benefit from global warming? Accounting for irrigation in the hedonic approach", American Economic Review, 95(1), 395-406, 2005.

[4] Alemayehu ST, Dorosh P, Gemessa SA, "Crop production in Ethiopia: Regional patterns and trends. Food and agriculture in Ethiopia", Progress and policy challenges, 74, 53, 2012.

[5] OIDA (Oromia Irrigation Authority), "East Wollega Zone Irrigation Development Authority: Dadabi small scale irrigation feasibility study", 2009.

[6] Zhang X, Yang F, "RclimDex (1.0) user manual. Climate Research Branch Environment Canada", P22, 2004.

[7] Stern R, Rijks D, Dale I, Knock J, "Instat Climatic Guide. Reading, UK: Statistical Services Centre", Reading University, 2006.

[8] Giorgi F, Jones C, Asrar GR, "Addressing climate information needs at the regional level: the CORDEX framework. World Meteorol Organ (WMO) Bull 58(3):175-183, 2009

[9]Teutschbein C, Seibert J, (2012) "Bias correction of regional climate model simulations for hydrological climate-change impact studies: Review and evaluation of different methods", Journal of Hydrol., 456, 12-29, 2012.

[10] Hendrik R, Katrin B, Raghavan S, Indrajeet Ch, Jeffrey GA, "Documentation for preparing simulated climate change data for hydrologic impact studies", CMhyd User Manual, 2016.

[11] Hargreaves GH, Samani ZA, "Reference crop evapotranspiration from ambient air temperature", American Society of Agricultural Engineers, USA, 1985.

[12]Gemechu T, "Impact of Climatological Parameters on Crop Water Use of Maize and Sorghum: A Case of Adami-Tulu JidoKombolcha woreda, Central Rift Valley of Ethiopia", Journal of Earth Science \& Climatic Change. $\quad$ DOI: $\quad 10.4172 / 2157$ 7617.1000370,2016

[13]Mohan S, Ramsundram N, "Climate Change and its Impact on Irrigation Water Requirements on 


\section{International Journal of Engineering Applied Sciences and Technology, 2020 \\ Vol. 4, Issue 9, ISSN No. 2455-2143, Pages 452-464 \\ Published Online January 2020 in IJEAST (http://www.ijeast.com)}

Temporal Scale, Irrigation \& Drainage Systems engineering research article, India, 2014

[14] MoA, "Guideline on irrigation agronomy manual revised version", Addis Ababa, Ethiopia. Page 218, September, 2011

[15] Federal Democratic Republic of Ethiopia Central statistical Agency, "Population Survey report on Livestock and Livestock characteristics", Volume 2, 201/17

[16] WHO, "Right to water. Retrieved from Office of the United Nations High Commissioner for HumanRights",http://www2.ohchr.org/English/i ssues/water/docs/Right_to_Water.pdf, 2003.

[17] OLFRDB (Oromia Livestock and Fishery Resource Development Bureau, "Oromia regional state Central statistical Agency Agricultural sample Survey report on Livestock and Livestock characteristics" Volume 2,2016/17

[18] Tibebe M, Birhanu ZB, "Water Demand Analysis and Irrigation Requirement for Major Crops at Holetta Catchment, Awash Sub-basin, Ethiopia”, Journal of Natural Sciences Research, 5(15), 117-128, 2015

[19] Adeba D, Kansal ML, Sen S, “Assessment of water scarcity and its impacts on sustainable development in awash basin, Ethiopia”. Sustainable Water Resources Management, 1(1), 71-87, 2015.

[20] Awulachew SB, Yilma AD, Loulseged M, Loiskandl W, Ayana, "Water resources and irrigation development in Ethiopia", Vol. 123, IWMI,2007.

[21] OIDA (Oromia Irrigation Development Authority), "Oromia irrigation potential Assessment report, Abbay River basin Interim Report", Volume VI: Irrigation Agronomy, 2017.

[22]MOWE (Ministry of Water and Energy),"Ethiopian-Nile Irrigation and Drainage Project: Consultancy services for feasibility study, detail design and preparation of tender documents of irrigation and drainage projects in the Nile basin of Ethiopia", 2012.

[23] Enyew BD, Van Lanen $\mathrm{H}$, Van Loon AF, "Assessment of the Impact of Climate Change on Hydrological Drought in Lake Tana Catchment, Blue Nile Basin, Ethiopia", J Geol Geosci 3: 174 . Doi: 10.4172/23296755.1000174, 2014.

[24] Gebre SL, Ludwig F, "Hydrological response to climate change of the upper Blue Nile River Basin: based on IPCC Fifth Assessment Report", J Climatol Weather Forecasting, 3(121), 2015.
[25] Mekonnen D, Diga GM, Rao GN, "Evaluating Potential Impact of Climate Change on Hydrometeorological Variables in Upper Blue Nile Basin: A Case Study of Fincha Sub-Basin", International Conference on Climate Change Effects, 2013

[26] Boru GF, Gonfa ZB, Diga GM, "Impacts of climate change on stream flow and water availability in Anger sub-basin, Nile Basin of Ethiopia" Sustainable Water Resources Management, 5(4), 1755-1764, 2019.

[27] FAO, "Crop water requirements", In: J. Doorenbos and W.O.prutt (eds). FAO irrigation and drainage paper 24, Rome Italy, 1984. 